\title{
Management of Conventional Orchards Shaping the Reproductive Bird Community
}

\author{
Sławomir CHMIELEWSKI \\ Address: Institute of Technology and Life Sciences, Falenty, Al. Hrabska 3, 05-090, Raszyn, Poland, \\ https://orcid.org/0000-0003-2686-6497 \\ $\bowtie:$ sch6@wp.pl
}

\begin{abstract}
The aim of this research was to characterise the breeding bird assemblage inhabiting an intensively cultivated, conventional apple orchard in central Poland $\left(51^{\circ} 41^{\prime} 45.1^{\prime \prime} \mathrm{N}, 20^{\circ} 42^{\prime} 08.9^{\prime \prime} \mathrm{E}\right)$ and to assess the consequences of this kind of management. The density of birds in such habitats is high, but the species composition is poor. Breeding success was evaluated and habitat parameters were described. The chemicals currently applied do not appear to restrict the species composition of breeding birds. A bigger problem in this context emerges from how the trees are trained and spaced in such an orchard: the crowns are pruned into a small, elongated rectangle and frequently thinned, and the tree density is high. This study is the first one published in Poland that provides definitive evidence of the harmful consequences to breeding birds of intensifying cultivation in apple orchards.
\end{abstract}

\section{Research Article}

$\begin{array}{ll}\text { Article History } & \\ \text { Received } & : 04.04 .2020 \\ \text { Accepted } & : 18.05 .2020\end{array}$

\author{
Keywords \\ Intensification of agriculture \\ Birds in orchards \\ Habitat characteristics \\ Breeding success
}

To Cite : Chmielewski S. 2020. Management of Conventional Orchards Shaping the Reproductive Bird Community. KSU J. Agric Nat 23 (6): 1698-1703. DOI: 10.18016/ksutarimdoga.vi.714681.

\section{INTRODUCTION}

Poland is one of the world's foremost producers of fruit. According to FAOSTAT, Poland was one of the leading producers worldwide in 2013 of sour cherries, blackcurrants, gooseberries, apples, raspberries and bilberries (Kierczyńska, 2016). In 2018, the acreage given over to fruit growing in orchards was 243000 ha, of which 175000 ha were apple orchards (Niszczota et al., 2019). Between 2012 and 2017 there was a distinct fall in the acreage of apple orchards with trees 15 and more years old (Niszczota, 2018). More than $43 \%$ of such orchards were planted at densities of 1600-3199 trees per ha, with such densities prevailing in nearly $64 \%$ of the youngest plantations (up to 4 years old) Niszczota, 2018). Polish fruit growers are thus tending to rejuvenate their orchards and to increase fruit tree density per ha. This change in management approach must affect the qualitative and quantitative structure of the bird assemblages breeding in orchards. Apart from studies of orchard birdlife in Wielkopolska province carried out 30-40 years ago, this problem has not been addressed in Poland (Tryjanowski et al., 2009), except for the work by Wiacek and Polak (2008) performed in the Sandomierz area in 2005. The province of Mazovia (Mazowsze), where Polish apple production is concentrated ( $45.6 \%$ of the orchard acreage there), has not been investigated in this respect. The present research is a continuation of the project (Chmielewski, 2016, 2019) aimed at assessing the state of the birdlife inhabiting orchards in Mazovia and identifying the threats to it posed by such intensive management.

Modern orchards are a completely artificial environment. Intensive orchard management practices subject the birds inhabiting it to severe stress. The frequent application of chemicals, the herbicide fallows between the rows of trees and the narrow, frequently thinned tree crowns compel the birds to adapt to this kind of crop. The broad spectrum of chemicals used in orchards may adversely affect their health, population size and reproductive success (Wilson et al., 1999, Boatman et al., 2004, Genghini et al. 2006, Bright et al. 2008). Bird assemblages in intensively managed orchards have not been studied, so it is not possible to suggest any meaningful measures to conserve the birds inhabiting them.

\section{MATERIAL and METHODS}

This research took place in an intensively cultivated, conventional apple orchard. The actual study plot (1 ha), in the shape of an elongated rectangle, lay to the

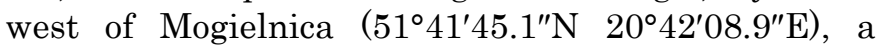
town in the district of Grójec (province of Mazovia). The 2659 trees in the orchard, 15 years old, were of the Jonagored variety. The trees had been planted in rows at a spacing of ca $1.0 \mathrm{~m}$ with the rows ca $3.0 \mathrm{~m}$ apart. The height of the trees excluding suckers was 2.5-2.7 $\mathrm{m}$ and the crown width was ca $1.1 \mathrm{~m}$. This type of crown shape - a narrow, elongated rectangle is described in semi-dwarf orchards as a super-spindle leader crown, with the lateral shoots of more or less 
equal length along the whole guide. The trunk height was ca $0.5 \mathrm{~m}$. Throughout the breeding season the trees were regularly sprayed with agrochemicals, and a ca $1.6 \mathrm{~m}$ wide strip of herbicide fallow was maintained in the rows between the trees. The regrowing herbaceous vegetation between rows was mown at regular intervals. During the bird breeding season tree crowns were not thinned. The study plot was surrounded by conventional apple orchards.

The research was carried out in 2018. Between 13 April and 15 July, the whole study plot was searched for birds' nests 19 times, on average every 7 days. A total of 63 hours and 12 minutes were spent in the field. One search of the whole plot took an average of 3 hours and 32 minutes and depended on the state of the foliage on the trees. When this had developed to the full, nest searches took longer, sometimes more than 5 hours, as nests were then harder to find. In the field, the trees and their concrete supporting posts were marked in order to ensure correct orientation and to pinpoint the exact location of a nest on a sketch-map. A successful brood was taken to be one where the young birds had fledged: they had been seen leaving the nest, or evidence of this, such as excreta or feather sheaths, was found in the nest. The length of the breeding season for particular species, i.e. from the start of nest building to the fledging of the young birds, was estimated from the advancement of nest construction, brooding dates or nestling age. The clutch/brood period (brooding, the nestling period), including the speed of nest building in particular species, was defined after Gotzman and
Jabłoński (1972) and Hudec (1983). In addition, the presence and behaviour of birds were noted during the nest searches in accordance with the cartographic method (Tomiałojć, 2014). The criterion for treating a species as breeding and calculating the number of pairs on the study plot was the finding of a nest.

The statistical calculations were performed in the SPSS Statistics 23 program. It was assessed whether the breeding species on the study plot built their nests more often in certain positions: A - on a lateral branch, B - at the top of a tree, $\mathrm{C}$ - adjacent to the main trunk. The $\mathrm{X}^{2}$ test was carried out for a single sample, or exact tests if the assumptions were not fulfilled. Then it was checked whether the height of a nest above the ground differed with respect to species: one-way ANOVA was performed to compare these groups. Nest success with respect to nest position $(\mathrm{A}, \mathrm{B}, \mathrm{C})$ was assessed with Fisher's exact test.

\section{RESULTS}

A total of 74 completed or unfinished nests were found on the study plot between mid-April and midAugust. The species of bird involved was established in 57 cases and the result of breeding in 45 cases. Five species bred in the orchard, of which song thrush Turdus philomelos and blackbird T. merula were the most numerous (Table 1). Chaffinch Fringilla coelebs was the first species to begin breeding, while linnet Linaria cannabina was the last to complete breeding (Table 1.).

Table 1. Number of pairs and breeding dates established on the basis of nest histories.

\begin{tabular}{|c|c|c|c|c|c|c|}
\hline \multirow[t]{2}{*}{ Species } & \multirow{2}{*}{$\begin{array}{l}\text { Number of } \\
\text { breeding pairs }\end{array}$} & \multirow[t]{2}{*}{ No. of clutch/brood } & \multirow[t]{2}{*}{ Clutch/brood date } & \multicolumn{3}{|c|}{$\begin{array}{l}\text { Type of nest } \\
\text { position }\end{array}$} \\
\hline & & & & $\mathrm{A}$ & $\mathrm{B}$ & $\mathrm{C}$ \\
\hline \multirow[t]{3}{*}{ Turdus philomelos } & 6 & $1^{\text {st }}$ & 15 April - 23 May & & & 6 \\
\hline & 5 & $2^{\text {nd }}$ & 11 June - 24 July & 1 & & 4 \\
\hline & 7 & repeat & 14 May - 2 July & & & 7 \\
\hline \multirow[t]{3}{*}{ Turdus merula } & 5 & $1^{\text {st }}$ & 23 April - 12 June & & & 5 \\
\hline & 4 & $2^{\text {nd }}$ & 7 June - 27 July & & & 4 \\
\hline & 1 & repeat & 24 May - 29 June & & & 1 \\
\hline \multirow[t]{3}{*}{ Fringilla coelebs } & 4 & $1^{\text {st }}$ & 13 April - 18 May & & & 3 \\
\hline & 3 & $2^{\text {nd }}$ & 25 June - 31 July & & & 2 \\
\hline & $\min .2$ & repeat & 18 May - mid-June & & & \\
\hline \multirow[t]{3}{*}{ Serinus serinus } & 2 & $1^{\text {st }}$ & 23 April - end of May & 1 & & 1 \\
\hline & 2 & $2^{\text {nd }}$ & 14 June - 1 August & 1 & 1 & \\
\hline & 2 & repeat & end of May - $1^{\text {st }}$ half of June & & 1 & 1 \\
\hline \multirow[t]{3}{*}{ Linaria cannabina } & 3 & $1^{\text {st }}$ & 28 April - 29 May & & 1 & 2 \\
\hline & 3 & $2^{\text {nd }}$ & 8 July - 22 August & & 2 & 1 \\
\hline & 2 & repeat & 1 June - 2 July & & 1 & 1 \\
\hline $1^{\text {st }}$ clutches total & \multirow{3}{*}{\multicolumn{2}{|c|}{$\begin{array}{l}20 \text { pairs/ha } \\
17 \text { pairs/ha } \\
\text { none }\end{array}$}} & \multirow{3}{*}{ From 13 June to 22 August } & 1 & 1 & 17 \\
\hline $2^{\text {nd }}$ clutches & & & & 2 & 3 & 11 \\
\hline $3^{\text {rd }}$ clutches & & & & & & \\
\hline Repeat clutches & \multicolumn{3}{|c|}{14} & & 2 & 10 \\
\hline Total & \multicolumn{3}{|c|}{47} & 3 & 6 & 38 \\
\hline
\end{tabular}

The most frequent nest position was adjacent to the

main trunk $(\mathrm{C}=80.8 \%)$, followed by the tree top 
position ( $\mathrm{B}=12.8 \%)$; the remaining nests were built on a lateral branch, albeit just 4-7 $\mathrm{cm}$ from the main trunk. It was mainly linnet that built its nests at the top of a tree: half the linnet nests were built in this position, the remainder adjacent to the main trunk. Serin Serinus serinus constructed its nests in all three positions, roughly in equal proportions. The differences in position were significant for song thrush $\mathrm{X}^{2}(2)=30.33 ; \mathrm{p}<0.001$; blackbird $\mathrm{p}<0.001$ and chaffinch $p=0.007$, but the results relating to serin and linnet were not even at the statistical trend level (Table 2.).

All the trees in the orchard were of the same, standard height, a consequence of its management. Linnet and chaffinch built their nests at the greatest height (Table 2.). The second-clutch nests of song thrush and blackbird were built higher than the firstclutch ones. The height of the nest above the ground was assessed for interspecific differences using oneway ANOVA. No differences were found, however, even at the statistical tendency level $\mathrm{F}(4,41)=0.76$; $\mathrm{p}=0.555$ (Figure 1.).

Table 2. Nest height in metres.

\begin{tabular}{|c|c|c|c|c|c|}
\hline Species & Minimum & Maksimum & Mean & Standart deviation & Median \\
\hline Linaria cannabina & 0.9 & 2.6 & 2.2 & 0.75 & 2.5 \\
\hline Fringilla coelebs & 1.3 & 2.7 & 2.2 & 0.55 & 2.5 \\
\hline Serinus serinus & 1.0 & 2.6 & 1.76 & 0.79 & 1.5 \\
\hline \multirow[t]{6}{*}{ Turdus philomelos } & \multicolumn{5}{|l|}{$1^{\text {st }}$ clutch } \\
\hline & 0.9 & 2.3 & 1.4 & 0.52 & 0.96 \\
\hline & \multicolumn{5}{|l|}{$2^{\text {nd }}$ clutch } \\
\hline & 2.0 & 2.7 & 2.3 & 0.26 & 2.2 \\
\hline & \multicolumn{5}{|c|}{ All nests, including repeat clutches } \\
\hline & 0.9 & 2.7 & 1.9 & 0.54 & 2.2 \\
\hline \multirow[t]{6}{*}{ Turdus merula } & \multicolumn{5}{|l|}{$1^{\text {st }}$ clutch } \\
\hline & 1.2 & 2.2 & 1.9 & 0.42 & 2.1 \\
\hline & \multicolumn{5}{|l|}{$2^{\text {nd }}$ clutch } \\
\hline & 1.8 & 2.6 & 2.3 & 0.36 & 2.4 \\
\hline & \multicolumn{5}{|c|}{ All nests, including repeat clutches } \\
\hline & 1.2 & 2.6 & 2.1 & 0.39 & 2.2 \\
\hline
\end{tabular}

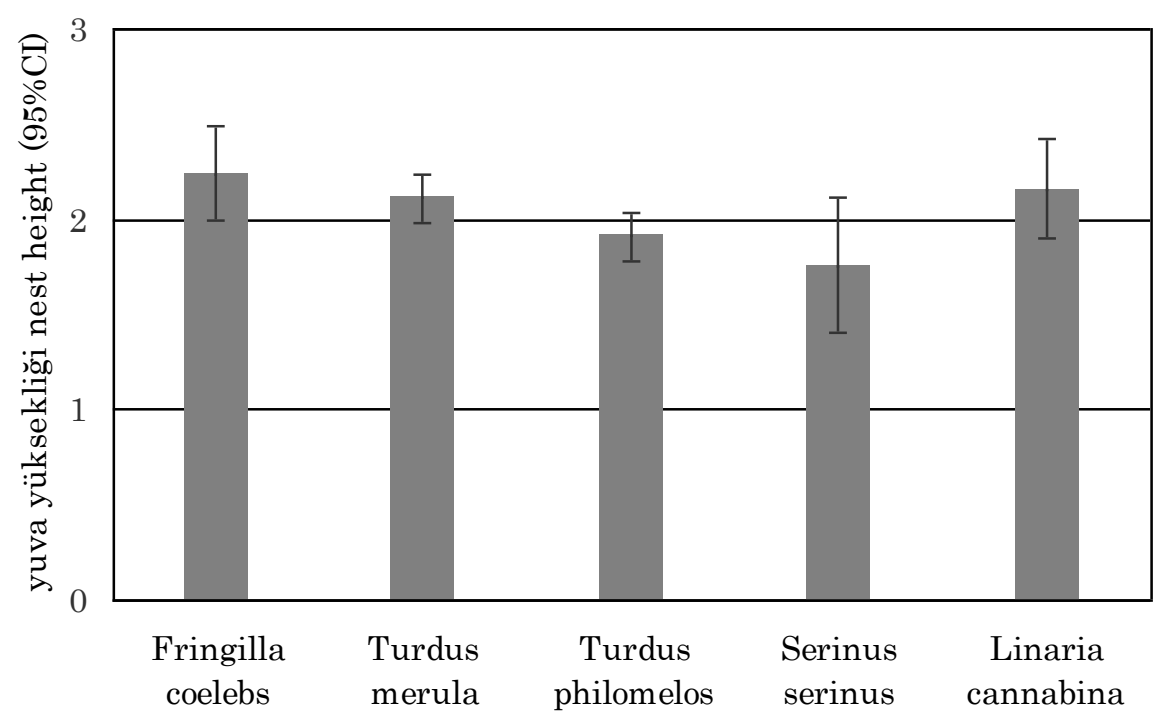

Figure 1. Nest height with respect to species. Mean values and standard errors are shown

Breeding success was calculated for 46 clutches: 28 (60.9\%) failed. Only 6 out of 19 (31.6\%) first clutches (1st) were successful, likewise 9 out of $16(56.3 \%)$ second clutches $\left(2^{\text {nd }}\right)$, and 4 out of $11(36.4 \%)$ repeat clutches. $78 \%$ of breeding attempts by song thrush failed, while the figure for blackbird was $50 \%$. Chaffinch sustained the least failures $(20 \%)$. In the case of first clutches, two out of five were successful in blackbird, and one out of three in linnet. All (100\%) the first clutches in song thrush $(n=6)$ and serin $(n=2)$ failed. In contrast, all the first clutches of chaffinch $(n=3)$ were successful. In the case of second clutches, two out of five were successful in song thrush, three out of four in blackbird, one out of two in chaffinch and serin, and two out of three in linnet. Clutch/brood losses were the least in late-June - early-July (Table 2.). Breeding success did not depend on nest position (A, B, C) (Fisher's exact test, $\mathrm{p}=0.292$ ). 
In addition, the territorial behaviour - mainly singing - of three further species was recorded in the study plot during the breeding season: yellowhammer Emberiza citrinella, greenfinch Chloris chloris and icterine warbler Hippolais icterina. They were not counted among the breeding birds, however, as no nests were found, and the short time they spent on the study plot suggested that they were nesting elsewhere.

\section{DISCUSSION}

In 2018, orchards made up 330967 ha (ca 2.3\%) of the overall acreage given over to agriculture in Poland (Niszczota, 2018). More than half of the apple and pear orchards were aged 5-14 years. Comparison of results from 2012 to 2017 shows that the area of orchards aged 15 and over has suffered a distinct decline. Many more apple orchards now have densities of $>1600$ trees per ha and far fewer have densities $<400$ trees per ha. The proportion of apple trees planted in densities of 1600-3199 trees per ha has increased by nearly $20 \%$; more than $43 \%$ of all apple orchards now have densities of this magnitude (Niszczota, 2018). These changes in management must affect the bird assemblage in intensively cultivated, conventional orchards. Tree crowns in such orchards have been reduced to a small, narrow rectangle in shape. Moreover, there are ca 20 applications of chemicals per year, and a strip of herbicide fallow is maintained between the rows of trees (Chmielewski, 2019; Grędziński, 2009; Kozanecka et al., 1996, Roper, 2004, Simon et al., 2010). Studies from intensively cultivated olive orchards in Spain and Portugal have demonstrated the negative effect of this form of management on the breeding bird assemblage there (Morgado et al., 2020, Rey et al., 2019).

A feature of the monoculture structure of apple trees in intensively cultivated, conventional orchards is the high transparency of crowns, which are no wider than 60-100 cm. Birds are thus compelled to adapt to such an "artificial" habitat. The data gathered in this study indicate that both the number of breeding bird species and their density are smaller in an orchard managed in such a way. 20 pairs per ha nested in the orchard of this type studied here (Table 1.). This is almost $50 \%$ fewer than in a traditional orchard (Chmielewski, 2019). Nevertheless, this is still a high density, generally comparable with that in rich alluvial forest habitats (e.g. 215 pairs/10 ha, Tomiałojć and Dyrcz, 1993), but with the important difference that the high densities in alluvial forests are due to the large percentage $(45-60 \%)$ of holenesters, not present in the studied orchard. Holes cannot form in orchard trees cultivated for less than 15-20 years because of the small circumference of their trunks (Grüebler et al., 2013). The species composition was also half that in a traditional orchard (5 vs. 10). Conspicuous by their absence were ground-nesters, and also breeding fieldfares Turdus pilaris, which commonly nest in traditional orchards, where the trees have broad, almost natural crowns (Chmielewski, 2019; Grędziński, 2009). Nest survivorship in this intensively cultivated, conventional orchard was the highest in late June and early July, in contrast to the traditional orchard, when this parameter peaked a month earlier (Figure 2.) (see Chmielewski, 2019). The birds were also building their nests with great intensity over a longer period of time than in a traditional orchard, from April until mid-July, even though there were half as many species. Taking into account all the nests found, i.e. completed and unfinished ones, and those of unidentified species, the nest density in the studied orchard was 74 per ha as against 82 in a traditional orchard (Chmielewski, 2019). The high density of nests in this orchard, in contrast to the lower overall density and the 50\% fewer species than in a traditional orchard, is probably a response to nest losses brought about by intensive management. The habit of the tree crowns may be the reason why some nests are destroyed when the tractor spraying chemicals at high pressure passes by: the small, narrow crown cannot prevent a flimsily attached nest from collapsing. This could be why most of the nests were built hard up against the main trunk.

It is surprising to note, therefore, the breeding success of $39.1 \%$, which was higher than in a traditional orchard (Chmielewski, 2019). Chaffinch and blackbird, and to a lesser extent song thrush, all achieved a better breeding success in this orchard than in a traditional one. In comparison with conventional orchards near Czersk and Brzumin (Grędziński, 2009), the form of management in the studied orchard favoured a high level of breeding success in blackbird but not in song thrush. As in traditional orchards, first clutches were more likely to fail than second and repeat clutches (Chmielewski, 2019). This suggests that the development of foliage, which better conceals nests, can reduce nest losses.

The uniform height and habit (narrow, regular crown) of the orchard trees restricted nest siting. No significant differences were found in nest height or nest position among the species. Linnet built its nests higher up in this intensively cultivated, conventional orchard than in a traditional one (Me 2.5 vs. 1.7), whereas the reverse held for serin (Me 1.5 vs. 2.4)(cf. Chmielewski, 2019). Song thrush built its nests in the same way in both types of orchard, i.e. higher up for the second clutch than for the first one; the same applied to blackbird. Intensification of cultivation, especially the application of pesticides in orchards, is considered to reduce the availability of food, which in turn impoverishes their birdlife (e.g. Bouam et al., 
2017; Bouvier et al., 2011; Solomou and Sfougaris, 2015). Equally, the intensive management of an orchard may severely restrict nesting opportunities (Morgado, 2020). Similar inferences can be drawn from the present research. They are corroborated by the study in the orchards near Brzumin and Czersk, which demonstrated that birds were less likely to build nests in a young, conventional orchard than in an older, conventional one (Grędziński, 2009).

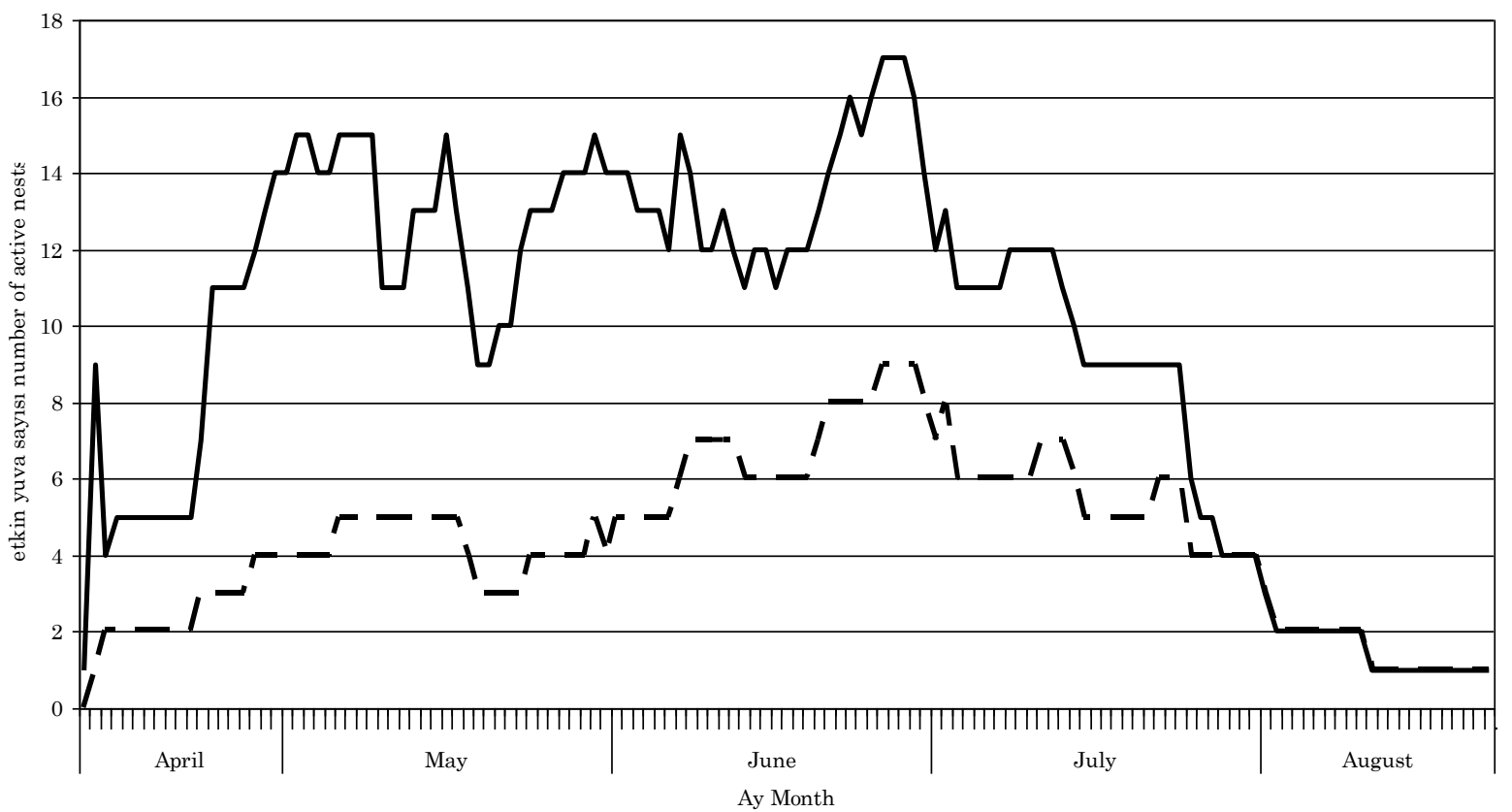

Figure 2. Survivorship (number of nests/day) of nests with successful clutches/broods (dashed line) compared with all nests (solid line).

In a traditional orchard near Mogielnica, where pesticides were not applied, the species composition was almost identical to that in the conventional orchards near Czersk and Brzumin, but 50\% poorer than in the intensively cultivated, conventional orchard studied here. This leads one to surmise that the species composition of breeding birds in such an orchard is not limited by the chemicals applied to the fruit trees, but rather by the way that the trees are planted and managed, i.e. the small, narrow, frequently thinned rectangular crowns, and the high tree densities.

\section{CONCLUSIONS}

The habit of a tree crown affects the density and species composition of birds colonising intensively cultivated, conventional apple orchards with high tree densities. This is confirmed by comparative studies carried out in different types of apple orchards (Chmielewski, 2019, Grędziński, 2009). In the studied orchard, the technique of pruning and shaping tree crowns, as well as the strip of herbicide fallow between the rows of trees and the age of the orchard, probably impoverished the species composition and reduced the density of birds. Moreover, it is very likely that these were the reasons for the absence of fieldfare and ground-nesting birds.

Action is necessary to limit the negative consequences of intensive orchard management. This can be done by offering fruit growers direct economic incentives in order to encourage them to reduce the intensity of cultivation in their orchards, e.g. as one aspect of agro-environmental programmes or by way of increasing financial support for organic farming (Morgado, 2020). Orchard biodiversity is enhanced by not removing herbaceous plants, hedges and even solitary trees on balks, and by installing nest boxes (Manning et al., 2006; Morelli et al., 2013; Jedlicka et al., 2014; Castro-Caro et al., 2015). Such action is imperative if we wish to maintain a high level of biodiversity in our farming landscape.

\section{Conflict of Interest}

The authors declare no conflict of interest.

\section{REFERENCES}

Boatman ND, Brickle NW, Hart JD, Milson TP, Morris AJ et al. 2004. Evidence for the indirect effects of pesticides on farmland birds. Ibis 146: 131-143.

Bouam I, Bachir A, Katayama N 2017. Variation in bird assemblages along an agricultural intensification gradient: A case study of olive orchards in North-Eastern Algeria. Ornithological Science 16: 147.

Bouvier JC, Ricci B, Agerberg J, Lavigne C 2011. 
Apple orchard pest control strategies affect bird communities in southeastern France. Environmental Toxicology and Chemisty 30: 212219.

Bright JA, Morris T, Winspear RJ 2008. A review of indirect effects of pesticides on birds and mitigating land-management practices. RSPB Research Report No 28. p. 66.

Castro-Caro JC, Barrio IC, Tortosa FS 2015. Effects of hedges and herbaceous cover on passerine communities in Mediterranean olive groves. Acta Ornithologica 50: 180-192.

Chmielewski S 2016. Breeding avifauna of orchards and adjacent habitats at Wysoczyzna Rawska (the Rawska Hills). Ornis Polonica 57: 29-39 [In Polish].

Chmielewski S 2019. The importance of old, traditionally managed orchards for breeding birds in the agricultural landscpape. Polish Journal of Environemental Studies. 28: 3647-3654.

Genghini M, Gellini S, Gustin M 2006. Organic and integrated agriculture: the effects on bird communities in orchard farms in northern Italy. Biodiversity and Conservation 15: 3077-3094.

Grüebler MU, Schaller S, Keil H, Naef-Daenzer B 2013. The occurrence of cavities in fruit trees: effects of tree age and management on biodiversity in traditional European orchards. Biodiversity and Conservation 22: 3233-3246.

Grędziński P 2009. Breeding ecology of the Birds in intensiva farmer orchards. Engineering work, SGGW, Warsaw. 36 p. [In Polish].

Gotzman J, Jabłoński B 1072. The nests of our birds. PZWS, Warsaw. 284 p. [In Polish].

Jedlicka JA, Letourneau DK, Cornelisse TM 2014. Establishing songbird nest boxes increased avian insectivores and reduced herbivorous arthropods in a Californian vineyard. USA. Conservation Evidence 11: 34-38.

Kierczyńska S 2016. Changes in the assortment's structure of fruit trees and shrubs cultivated in Poland. Roczniki Naukowe Stowarzyszenia Ekonomistów Rolnictwa i Agrobiznesu, 18: 158163. [In Polish].

Kozanecka T, Rekosz-Burlaga H, Russel S 1996. Effect of apple orchard soil management system, liming and nitrogen fertilization in biological activity. Roczniki Gleboznawcze. 47: 75-84.

Hudec K, Eds. 1983. Fauna ČSSR, Volume 23-24, Birds - Aves, III/1-2 . Akademia, Praha, 704 p. [In Czech].

Manning AD, Fischer J, Lindenmayer DB 2006. Scattered trees are keystone structures: implications for conservation. Biological Conservation 132: 311-321.

Morelli F 2013. Relative importance of marginal vegetation (shrubs, hedgerows, isolated trees) surrogate of HNV farmland for bird species distribution in Central Italy. Ecological Engineering. 57: 261-266.

Morgado R, Santana J, Porto M, Sánchez-Oliver JS, Reino L et al. 2020. Mediterranean silent spring? The effects of olive farming intensification on breeding bird communities. Agricultire, Ecosystems and Environment. 288: 106694.

Niszczota S 2018. Horticultural production. Orchard survey in 2017. Central Statistical Office, Warsaw, 10 p. [In Polish].

Niszczota S, Dziubiński K, Kupidura A, Miziołek D, Pacuszka R et al. 2019. Production of agricultural and horticultural crops in 2018. Central Statistical Office. Warsaw, 89 p. [In Polish].

Rey PJ, Manzaneda AJ, Valera F, Alcantara JM, Tarifa $\mathrm{R}$ et al. 2019. Landscape-moderated biodiversity effects of ground herb cover in olive groves: implications for regional biodiversity conservation. Agriculture, Ecosystems and Environment, 277: 61-73.

Roper TR 2004. Orchard flor management for fruit trees. Collage of agricultural and life sciences, University of Wisconsin Madison and university of Wisconsin-Extension publication, 608: 262-267.

Solomou AD, Sfougaris AI 2015. Bird community characteristics as indicators of sustainable management in olive grove ecosystems of Central Greece. Journal of natural history 49: 301-325.

Tomiałojć L 2014. The combined version of the Mapping Method. Mikusek R., Stawarczyk T. Eds. Ornithologist Guide. Wydawnictwo Fundacja Wspierania Inicjatyw Ekologicznych, Kraków, 280 p. [In Polish].

Simon S, Bouvier JC, Debras JF, Sauphanor B 2010. Biodiversity and pest management in orchard systems. A review. Agronomy for Sustainable Development, 30: 139-152.

Tomiałojć L, Dyrcz A 1993. Nature conservation in large river valleys of Poland: an ornitological Outlook. Tomiałojć L. Eds. Nature and environment conservation in the lowland river valleys of Poland. IOP PAN, Kraków, 13-38. [In Polish].

Tryjanowski P, Kuźniak S, Kujawa K, Jerzak L 2009. Ecology of farmland birds. Bogucki Wydawnictwo Naukowe, Poznań, 390 p. [In Polish].

Wiaccek J, Polak M 2008. Bird community breeding in apple orchards of Central Poland in relation to some habitat and management features. Polish Journal of Environmental Studies 17: 951-956.

Wilson JD, Morris AJ, Arroyo BE, Clark SC, Bradbury RB 1999. A review of the abundance and diversity of invertebrate and plant foods of granivorous birds in the northern Europe in relation to agricultural change. Agriculture, Ecosystems and Environment 75: 13-30. 